\title{
DEPARTMENT OF SERA AND VACCINES PRODUCTION IN NATIONAL INSTITUTE OF HYGIENE IN THE YEARS 1919-1951
}

\author{
ZAKŁAD PRODUKCJI SUROWIC I SZCZEPIONEK PAŃSTWOWEGO \\ ZAKŁADU HIGIENY W LATACH 1919-1951
}

\author{
Narodowy Instytut Zdrowia Publicznego - Państwowy Zakład Higieny, Warszawa
}

\begin{abstract}
The statute of the National Institute of Hygiene from 1923 apart from research and diagnosing of infectious diseases, their sources, ways of spreading and fighting defined: ,production and research of sera, vaccines, cowpox and other bacterial products". These targets were realized since 1919 along as the technology of production developed and the demand in prevention and fighting of infectious diseases increased. Sera and bacterial strains were investigated in Department of Bacteriology and Experimental Medicine in NIH and controlled Department of Sera and Vaccines. The technology of production was coordinated with foreign scientific centers and commissions of League of Nations. Since 1925 Department produced 10 species of medical sera and 32 species of various vaccines. Production was relocated to Warsaw Manufacture of Sera and Vaccines in the year 1951.
\end{abstract}

\section{STRESZCZENIE}

Statut Państwowego Zakładu Higieny z 1923 r. oprócz rozpoznawania chorób zakaźnych, badania ich istoty, źródeł powstawania, sposobów szerzenia i zwalczania określał „wyrób i badania doświadczalne surowic, szczepionek, krowianki i innych produktów bakteryjnych".

Cele te były realizowane od 1919 r. w miarę rozwoju technologii wytwarzania tych produktów i zapotrzebowania w dziedzinie profilaktyki i zwalczania chorób zakaźnych. Surowice i szczepy bakterii do wyrobu szczepionek były badane w Dziale Bakteriologii i Medycyny Doświadczalnej PZH i kontrolowane w Dziale Badania Surowic i Szczepionek, a ich technologia była uzgadniana z zagranicznymi ośrodkami naukowymi i komisjami Ligi Narodów. Od 1925 r. Zakład produkował 10 gatunków surowic leczniczych i 32 gatunki różnych szczepionek.

Produkcja surowic i szczepionek w 1951 r. została przeniesiona z PZH do Warszawskiej Wytwórni Surowic i Szczepionek.

Państwowy Zakład Epidemiologiczny którego początki sięgają października 1918 r. (pierwsza nazwa Państwowego Zakładu Higieny) przejął zakłady prywatne produkujące surowice i szczepionki:

- Zakład Wyrobu Surowic Towarzystwa Naukowego Warszawskiego

- Zakład Wyrobu Krowianki D-ra Józefa Tchórznickiego

- Zakład Szczepienia przeciw wodowstrętowi D-ra Władysława Palmirskiego - późniejszy Pasteurowski.

- Zakłady usytuowano na parterze i na I piętrze budyn$\mathrm{ku}$ (obecnie $\mathrm{AB}$ ) zakupionego przez Ministerstwo Zdrowia Publicznego w 1919 r., a w 1920 r. wyposażono je we wszystkie niezbędne urządzenia do produkcji surowic i szczepionek
Od 1919 r. produkowano na wielką skalę szczepionki ochronne i zaopatrywano w nie wojsko i ludność cywilną. Szczególnie ważna była ta działalność w czasie wojny polsko-bolszewickiej. W 1919 r. wyprodukowano 862 litry szczepionek, ale zapotrzebowanie zaczęło się zmniejszać w miarę jak wygasały epidemie. W 1923 r. wyprodukowano tylko 234 litry szczepionek ochronnych.

W 1922 r. zaczęto produkować szczepionki suche metodą Besredki: przeciwcholeryczną, przeciwczerwonkową i przeciwtyfusową. Cała produkcja była w tym czasie zużyta przez Generalną Dyrekcję Służby Zdrowia i wojsko do przeprowadzenia szczepień ludności na terenach, gdzie endemicznie panował dur brzuszny i czerwonka.

(C) National Institute of Public Health - National Institute of Hygiene / Narodowy Instytut Zdrowia Publicznego - Państwowy Zakład Higieny 
Szczepionki produkowane w PZH były stosowane za granicą. Wysyłano duże ilości szczepionek przeciwdurowych, przeciwcholerycznych i przeciwczerwonkowych do Rosji. Liga Narodów przeprowadziła szczepienia polskimi szczepionkami płynnymi wśród ludności greckiej.

W 1924 r. była sporządzona szczepionka paciorkowcowa płonicza z paciorkowców wyhodowanych z krwi chorych na płonicę, która zawierała bakterie zabite ciepłem pod nazwą szczepionki Gabryczewskiego. Gdy opracowano nową szczepionkę Dicków, Zakład jako pierwszy w Europie przeprowadzał badania nad stosowaniem toksyny paciorkowcowej płoniczej jako szczepionki ochronnej i produkował tzw. „szczepionkę przeciwpłoniczą PZH", która była zmodyfikowaną szczepionką Gabryczewskiego i Dicków według metody Celarka.

Od 1925 r. produkowano toksynę do odczynu Dick'ów, szczepionkę płoniczą (według Dick'ów oraz szczepionkę błoniczą . W końcu 1925 r. Zakład produkował 10 gatunków różnych surowic leczniczych i 32 różne szczepionki oraz preparaty diagnostyczne, jak surowice aglutynujące, antygeny itp.

Również w tym roku otrzymano szczep do wyrobu szczepionki przeciwgruźliczej Calmette'a. Od 1926 roku zaczęto wydawać szczepionkę lekarzom.

Państwowy Zakład Higieny wspólnie z Towarzystwem Przeciwgrużliczym organizował szczepienia przeciwgruźlicze na szerszą skalę i przeprowadzał badania ankietowe skuteczności szczepień.

Działem produkcji kierował dr Józef Celarek, który odbył studia w Ameryce jako stypendysta Fundacji Rockefellera. Zwiedził instytuty bakteriologiczne w Paryżu, Berlinie, Kopenhadze, Sztokholmie, Oslo, Londynie, Wiedniu, Bernie i Pradze, gdzie zapoznał się z najnowszymi metodami i urządzeniami do produkcji surowic i szczepionek, które zastosował w zakładzie, tak że nie było potrzeby sprowadzania zagranicznych preparatów.

\section{ODDZIAŁ WYROBU KROWIANKI OSPOWEJ}

Oddział Wyrobu Krowianki PZH zajmował się produkcją szczepionki ospowej. Największa produkcja była w okresie wiosennym, kiedy w Polsce przeprowadzano przymusowe szczepienia ochronne ludności przeciw ospie prawdziwej. Cała produkcja była wtedy przeznaczana na potrzeby Generalnej Dyrekcji Służby Zdrowia i samorządów.

Do wyrobu szczepionki używano jałówek 1-2 letnich wypożyczanych od właścicieli za odszkodowaniem. Jedna jałówka dostarczała około 30000 porcji szczepionki, W 1924 r. wyprodukowano 2434579 porcji krowianki, a w 19252543857 porcji.

Próbowano też hodować zarazki krowianki na błonie kosmówkowej omocznej zarodków kurzych.
Nie było żadnych reklamacji od lekarzy o nieprzyjmowaniu się szczepionki ospowej, ani nie zgłaszano powikłań poszczepiennych.

Kierownikiem Oddziału był dr Stanisław Zdanowicz.

\section{ODDZIAŁ WYROBU SUROWIC}

W Oddziale Wyrobu Surowic w chwili przejęcia go przez PZE było kilka koni, wyczerpanych długotrwałym uodpornianiem. Dopiero w marcu 1920 r., kiedy zakupiono fermę Służew, można było urządzić właściwie stajnie i powiększyć liczbę koni.

Surowice lecznicze trzeba było pozyskiwać z dużych zwierząt, od których można było uzyskać od razu kilka litrów surowicy. Wartość surowicy tzw. „surowice wysokowartościowe" zależała od wprawy i doświadczenia otrzymującego i od ustroju zwierzęcia (1). Surowice przeciwjadowe (antytoksyczne) otrzymywano przez wstrzyknięcie zwierzętom jadów bakteryjnych odsączonych od bakterii. Inne surowice otrzymywano przez szczepienie zwierząt zabitymi lub żywymi bakteriami chorobotwórczymi. Surowice otrzymywano po upływie kilku tygodni lub nawet miesięcy (2).

$\mathrm{W}$ produkcji surowic na pierwszym planie była surowica błonicza, potem tężcowa, płonicza, meningokokowa i paciorkowcowa. Do wyleczenia chorego potrzeba było $5-10 \mathrm{~cm}^{3}$ surowicy, często nawet więcej, a do zaszczepienia $2-3 \mathrm{~cm}^{3}$.

W 1921 r. Komitet Higieny Ligi Narodów postanowił ujednolicić miareczkowanie surowic. Powstała Komisja Standaryzacyjna Produktów Biologicznych wprowadzająca jednostki międzynarodowe do określania siły surowic i wzorce międzynarodowe przechowywane w Państwowym Instytucie Seroterapeutycznym w Kopenhadze, skąd wysyłano je za darmo do instytucji kontrolnych w poszczególnych państwach.

Produkowano surowice: błoniczą, czerwonkową, tężcową, meningokokową, paciorkowcową, pneumokokową, przeciw różycy świń (od 1923 r.), przeciw obrzękowi złośliwemu (od 1923 r.). Badano miano surowic: błoniczą na świnkach morskich - wymagane miano - 200 jednostek, surowicę przeciwczerwonkową na myszach, zgodnie z przepisami komisji Komitetu Higieny Ligi Narodów. Surowica przeciwpłonicza badana była na dzieciach, z wymaganiem, aby w rozcieńczeniu 1:50 zobojętniała 10 dawek skórnych (miana tej surowicy nie można było oceniać na zwierzętach), surowica meningokokowa była badana za pomocą układu dopełniacza i aglutynacji - wymagane miano - 1/200. Surowica tuberkulinowa badana była na świnkach gruźliczych metodą Calmette'a, albo na dzieciach za pomocą odczynu Pirquet'a. Wszystkie surowice były badane na jałowość (2).

W następnych latach w oddziale była już sala operacyjna dla zwierząt, podręczne laboratorium i ubi- 
kacje zaopatrzone w urządzenia sterylizacyjne, wodę zimną i ciepłą, centralne ogrzewanie i elektryczność.

Dokupiono też fermę Gołymin (200 ha) jako przedsiębiorstwo pomocnicze do produkcji paszy dla zwierząt doświadczalnych i ich hodowli.

\section{ODDZIAŁ SZCZEPIEŃ PRZECIW WODOWSTRĘTOWI (PASTEUROWSKI)}

Oddział Szczepień przeciw wodowstrętowi (Pasteurowski) - działał na początku jako Instytut szczepień przeciw wodowstrętowi, który założył w Warszawie Odo Bujwid w 1886 r., od 1893 był kierowany przez dr Władysława Palmirskiego i dr Zenona Karłowskiego. Przejęty przez Państwo Polskie od 1 marca 1919 r. funkcjonował samodzielnie jako Państwowy Instytut Pasteurowski, a następnie jako oddział Pasteurowski PZE, potem PZH.W następnych latach stanowił oddział Działu Produkcji Surowic i Szczepionek PZH.

Do 1927 r. produkowano szczepionkę przeciw wściekliźnie wg receptury Pasteura, a w latach 19281939 produkowano szczepionkę fenolizowaną wg Semple'a (3). Oddział posiadał laboratoria do wyrobu szczepionki przeciw wściekliźnie i ubikacje, gdzie szczepiono zgłaszające się osoby. W latach 1919-1923 zgłosiło się do szczepienia 7815 osób, zaszczepiono 6869, przeprowadzono szczepienie do końca 6729 osób, a 6 osób zmarło na wściekliznę.

Do 1925 r. osoby pokąsane były kierowane do Oddziału Pasteurowskiego i tam szczepione przeciw wściekliźnie, ale kiedy wprowadzono trwalszą szczepionkę karbolizowaną, można ją było wysyłać do aptek i pokąsani mogli się szczepić u swojego lekarza. W 1927 r. wysłano z Zakładu 191 litrów szczepionki, która wystarczała do zaszczepienia 5000 osób pokąsanych. Szczepionka przeciw wściekliźnie była produkowana również w oddziale Pasteurowskim filii PZH we Lwowie i tam też prowadzono szczepienia; np. w latach 1924-1925 w Warszawie zaszczepiono 4139 osób, a we Lwowie 3019.

Dział Produkcji utrzymywał się z własnych dochodów ze sprzedaży surowic i szczepionek, chociaż organizacyjnie należał do PZH.

Od lipca 1924 r. w Oddziale Pasteurowskim pracowała dr Wiera Głowacka. W 1927 r. została wydelegowana do Filii PZH we Lwowie, żeby zapoznała się ze sposobem przygotowania szczepionki wg metody Mulforda.

W Oddziale Pasteurowskim przyjmowała materiał do badań w godzinach pozaurzędowych i w dni świąteczne, załatwiała pilne zapotrzebowania aptek i szpitali na surowice i szczepionki oraz udzielała zgłaszającym się w nagłych przypadkach i szczepiła zgłaszające się osoby. 1 maja 1935 r. przejęła kierownictwo oddziału po doktorze Zenonie Karłowskim.

W oddziale pracował też od 1934 r. Stanisław Saski (1884-1963) bakteriolog kontraktowy, adiunkt i pełnił obowiązki p.o. kierownika Działu Surowic i Szczepionek od sierpnia 1939-1.08.1944 r.

\section{ROZWÓJ PRODUKCJI SUROWIC I SZCZEPIONEK W PZH I ICH KONTROLA}

W następnych latach Państwowy Zakład Higieny zwiększał produkcję i asortyment surowic i szczepionek. Niektóre z nich wyrabiane były w małych ilościach: np. pneumokokowa, przeciw zgorzeli gazowej i grypie, ale ponieważ były zamawiane przez lekarzy w Polsce, Zakład produkował je, aby zawsze były dostępne.

Warunki stosowania surowic w leczeniu określało Rozporządzenie Min. Spraw Wewnętrznych z 1932 r. (D U nr 64/32) oraz Instrukcja Ministerstwa Opieki Społecznej. Najważniejsza sprawą w kontroli surowic było oznaczenie wartości ich siły, tzw. miareczkowanie.

PZH brał udział w pracach naukowych inicjowanych przez Komitet Higieny Ligi Narodów nad miareczkowaniem surowic czerwonkowych i standaryzacją serodiagnostyki kiły i był reprezentowany na zjazdach w Genewie, we Frankfurcie i Kopenhadze, oraz na zjeździe w sprawie wścieklizny w Paryżu i w pracach komisji malarycznej Ligi Narodów.

Produkcja surowic i szczepionek oraz organopreparatów (insulina i pituitrol) odbywała się tak, aby sprostać wymogom rynku.W 1934 i 1935 r. produkowano i sprzedawano 23 różne surowice m.in. paciorkowcową, płoniczą, przeciw róży, zakażeniom połogowym, błoniczą, tężcową, czerwonkową, meningokokową, przeciw jadowi żmij, wąglikowi, przeciw chorobie Heine-Medina i 16 szczepionek ochronnych, m.in. choleryczną, durową, czerwonkową, płoniczą, błonicza, BCG dla dzieci i zwierząt, przeciw wściekliźnie, przeciwko ospie oraz 19 szczepionek leczniczo-ochronnych, preparatów diagnostycznych (surowice aglutynujące, precypitujące, hemolityczne, antygeny do odczynu na kiłę, cholesterynę do odczyny Bordet-Wassermana, zawiesiny bakteryjne do aglutynacji, odczynnik Dick'ów, odczynnik Schick'a, tuberkulinę, izoaglutyninę (4).

Pojawiały się nowe organopreparaty i istniała potrzeba kontroli, dlatego powołano specjalny Oddział Kontroli Biopreparatów i Witamin. Przy PZH istniała Komisja Organopreparatów, która rozpatrywała podania o rejestrację nowych produktów.

Dział Bakteriologii i Medycyny Doświadczalnej PZH współpracował z działem produkcji przy przygotowywaniu niektórych produktów biologicznych (obecność substancji pyrogennych, jałowość i tp.) i przekazywal je do Działu Produkcji Surowic i Szczepionek, który po ocenie wypuszczał je na rynek. W Dziale Produkcji prowadzono badania naukowe nad modyfikowaniem szczepionek, aby otrzymywać preparaty o mniejszej toksyczności i dających słabsze odczyny poszczepienne. Oddani swojej pracy lekarze dążąc do udoskonala- 
nia surowic i szczepionek zaszczepiali sobie zarazki, aby sprawdzić ich działanie, np. dr Helena Sparrow (pracowała w Zakładzie Badania Surowic i Szczepionek) zaszczepiła sobie zarazek duru brzusznego, a Dr Feliks Przesmycki (Dział Bakteriologii i Medycyny Doświadczalnej) wszczepił sobie zarazek duru osutkowego wyizolowanego przez Weila i Felixa i przechorowali te choroby ze wszystkimi objawami. Dr Przesmycki izolując szczepy meningokoków wywołujących nagminne zapalenie opon mózgowych podczas epidemii w Warszawie w 1919 r. identyfikował je przy pomocy surowic odpornościowych diagnostycznych i określał, jaki ich typ wywołał epidemię (3). Julia Seydel w specjalnie zorganizowanej pracowni błoniczej w PZH (od 1927 r.) badała szczepy wyizolowane podczas epidemii, aby najlepsze z nich zastosować do produkcji szczepionki.

W PZH produkowano preparaty weterynaryjne: surowicę przeciwko różycy świń, surowicę tężcową, szczepionkę BCG dla cieląt i przeciw tyfusowi mysiemu.

Ważne były doświadczenia nad zatężaniem surowic, od czego zależała efektywność szczepień.

Prywatne zakłady i pracownie korzystały $\mathrm{z}$ antygenów PZH, co dawało rękojmię do otrzymywania wy- ników porównywalnych na terenie państwa (głównie odczynnika dla diagnostyki kiły).

Z surowic leczniczych w $1936 \mathrm{r}$, było największe zapotrzebowanie na błoniczą (sprzedano 470 litrów.

W 1937 roku zapotrzebowanie na surowice i szczepionki bardzo wzrosło, bo prowadzono na szeroką skalę akcje szczepień ochronnych przeciwko błonicy, płonicy, durowi brzusznemu i czerwonce. Ministerstwo Opieki Społecznej i Ministerstwo Spraw Wojskowych zamówiły 10000 litrów szczepionki przeciwczerwonkowej.

We wrześniu 1937 r. odbył się w PZH doroczny zjazd kierowników odpowiedzialnych za produkcję surowic i szczepionek z Państwowych zakładów Higieny w Warszawie, Pradze, Zagrzebiu, Sofii i Bukareszcie. Na zjeździe omawiano zagadnienia związane z ulepszeniem produkcji i wprowadzeniem nowych surowic i szczepionek oraz ich wymianę.

W tym czasie były plany przeniesienia całej produkcji surowic i szczepionek do Służewa,pod Warszawą, ale nie zostały zrealizowane.

W latach 30 . Oddziały produkcji surowic i szczepionek funkcjonowały jako jeden Dział Surowic i Szczepionek (tabele ze sprawozdań) PZH.

T A B L I C A IX.

Sprzedaż surowic.

\begin{tabular}{|c|c|c|c|c|c|}
\hline \multirow[b]{2}{*}{ Nazwa surowicy } & \multicolumn{2}{|c|}{$\begin{array}{lllll}1 & 9 & 3 & 7 & \mathrm{r}\end{array}$} & \multicolumn{2}{|c|}{$\begin{array}{lllll}1 & 9 & 3 & 6 & \mathrm{r}\end{array}$} & \multirow[b]{2}{*}{ U w a g i } \\
\hline & $\begin{array}{l}\text { Ilość } \\
w \mathrm{~cm}^{3}\end{array}$ & $\begin{array}{c}\text { Ilość } \\
\text { w jednost. }\end{array}$ & $\begin{array}{l}\text { llość } \\
w \mathrm{~cm}^{3}\end{array}$ & $\begin{array}{c}\text { Ilość } \\
w \text { jednost. }\end{array}$ & \\
\hline Błoniczo-końska . & 492.439 & 377.893 .000 & 460.647 & $390.284 .0 \cap 0$ & w tym konc. \\
\hline -barania & 12.840 & 3.072 .000 & 9.092 & 2.386 .000 & \\
\hline -bydlęca & 0.300 & 30.000 & 0.720 & 72.000 & \\
\hline Tężcowa końska & 867.980 & 433.990 .000 & 523.640 & 261.745 .000 & \\
\hline Czerwonkowa & 195.000 & $\begin{array}{l}493.500 \\
-\end{array}$ & $\begin{array}{r}0.990 \\
140.080\end{array}$ & - & $\begin{array}{l}\text { w tym } 10 \\
\text { ltr. Zagrzeb }\end{array}$ \\
\hline $\begin{array}{c}\text { Paciorkowcowa } \\
\text {, plonicza }\end{array}$ & $\begin{array}{l}119.910 \\
281.430\end{array}$ & - & $\begin{array}{l}120.640 \\
252.480\end{array}$ & - & $\begin{array}{l}\text { w tym stẹż. } \\
43.640\end{array}$ \\
\hline " p. róży ludz. & 59.030 & - & 60.240 & - & \\
\hline $\begin{array}{l}\text { p. zakaż. pol. } \\
\text { Meningokokowa }\end{array}$ & $\begin{array}{l}167.560 \\
389.070\end{array}$ & - & $\begin{array}{l}175.570 \\
265.370\end{array}$ & - & $\begin{array}{l}\text { w tym } \\
78.100 \text { zagr. }\end{array}$ \\
\hline Pneumokokowa. & 18.960 & - & 16.280 & - & \\
\hline P. zgorz. gaz. . & 143.830 & - & 85.610 & - & 45 ltr. zagr. \\
\hline P. jadowi kiel. . & 11.190 & 一 & 9.030 & - & $6 \mathrm{ltr}$. zagr. \\
\hline P. kokluszowa. . & 7.940 & 一 & 8.830 & - & \\
\hline P. grypowa . . . & 0.300 & - & 1.950 & - & \\
\hline P. B. Coli . . & 26.400 & - & 28.240 & - & \\
\hline P. gronkowcowa & 8.220 & 一 & 6.960 & - & \\
\hline P. waglikowa . & 5.440 & 一 & 3.400 & 一 & \\
\hline P. jadowi żmij . & 15.400 & - & 9.020 & 一 & \\
\hline $\begin{array}{l}\text { P. Heine-Medina } \\
\text { Normalna końska. }\end{array}$ & $\begin{array}{r}4.820 \\
48.000\end{array}$ & - & $\begin{array}{r}5.680 \\
46.064\end{array}$ & - & \\
\hline Anti-peritonitis & 17.240 & - & 5.910 & - & \\
\hline Razem: & 2.894 .709 & 815.478 .500 & 2.236 .443 & 654.833 .500 & \\
\hline
\end{tabular}

Tabela. I. Sprzedaż surowic w latach 1936-1937 (ze Sprawozdania PZH za rok 1937) 
T A B L I C A X.

Sprzedaż szczepionek ochronnych.

\begin{tabular}{|c|c|c|c|c|}
\hline \multirow[b]{2}{*}{ Nazwa szczepionki } & \multicolumn{2}{|c|}{$19937 \mathrm{r}}$. & \multicolumn{2}{|c|}{ 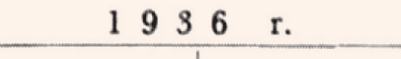 } \\
\hline & $\begin{array}{l}\text { Llość } \\
\text { w } \mathrm{cm}^{3}\end{array}$ & $\begin{array}{ll}\text { Ilośt } \\
\text { w dawkach }\end{array}$ & $\begin{array}{c}\text { Iloskt } \\
\mathrm{w} \mathrm{cm}^{3}\end{array}$ & \begin{tabular}{ll} 
& \multicolumn{1}{l}{$\begin{array}{l}\text { lość } \\
\text { dawkach }\end{array}$}
\end{tabular} \\
\hline 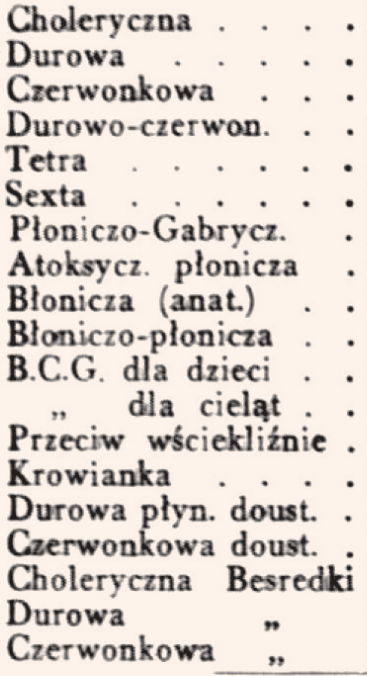 & $\begin{array}{r}2.010 \\
1.204 .825 \\
217.820 \\
31.850 \\
26.960 \\
52.110 \\
36.985 \\
1.315 \\
1.249 .635 \\
412.550 \\
= \\
761.000 \\
- \\
61.230 \\
5.649 .800 \\
- \\
-\end{array}$ & $\begin{array}{r}1.840 \\
803.216 \\
145.213 \\
21.233 \\
17.973 \\
34.740 \\
12.328 \\
438 \\
416.545 \\
137.516 \\
9.142 \\
529 \\
15.220 \\
2.038 .821 \\
2.041 \\
376.653 \\
- \\
- \\
-\end{array}$ & $\begin{array}{r}3.380 \\
1.047 .335 \\
238.750 \\
\overline{-} \\
25.300 \\
83.770 \\
12.620 \\
3.700 \\
724.195 \\
424.295 \\
\overline{-} \\
582.150 \\
\overline{-} \\
3.273 .000 \\
\overline{-} \\
-\end{array}$ & $\begin{array}{r}2.253 \\
698.223 \\
159.166 \\
\overline{16} .866 \\
55.846 \\
4.206 \\
1.233 \\
241.398 \\
141.491 \\
7.678 \\
315 \\
11.643 \\
1.758 .574 \\
\overline{2} \\
218.200 \\
50 \\
2.483 \\
440\end{array}$ \\
\hline Razem: & 08.090 & 4.032 .948 & 6.418 .495 & 3.320 .065 \\
\hline
\end{tabular}

Tabela II. Sprzedaż szczepionek ochronnych w latach 1936-1937 (ze Sprawozdania PZH za 1937 rok)

T A B L I C A XI.

Sprzedaż szczepionek leczniczych.

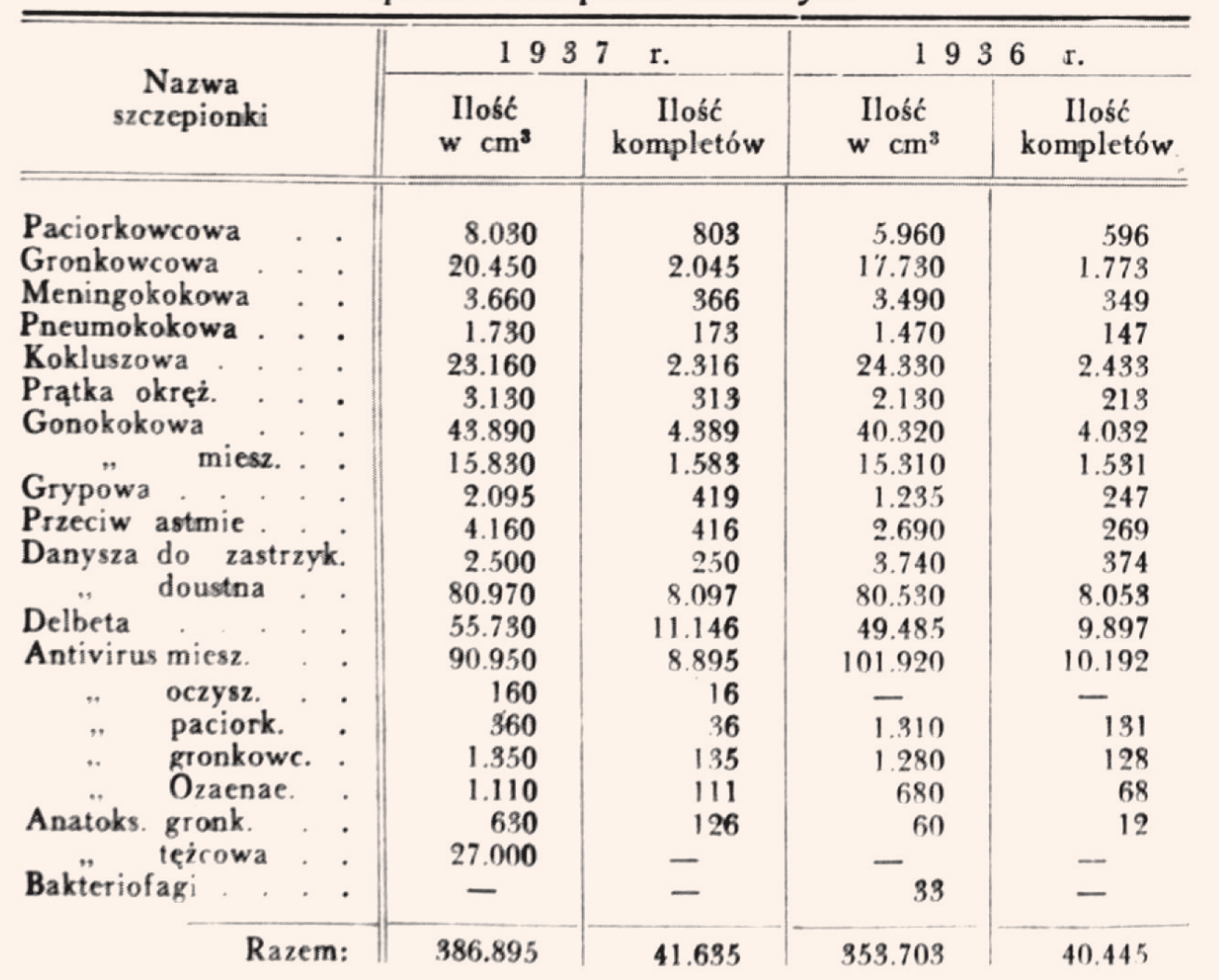

Tabela III. Sprzedaż szczepionek leczniczych w latach 1936 i 1937 (ze Sprawozdania PZH za 1937 rok) 
T A B L I C A XII.

Sprzedaż preparatów diagnostycznych.

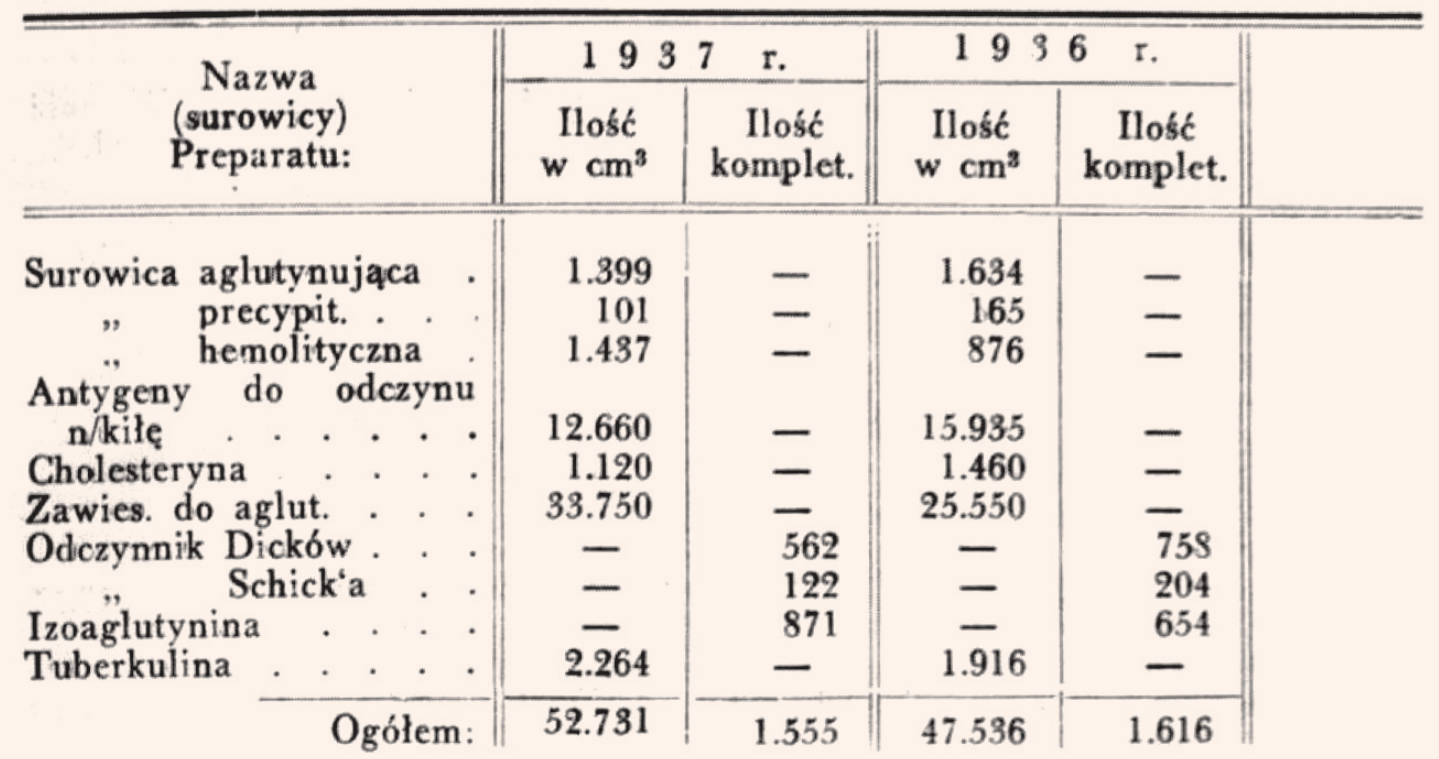

Tabela. IV. Sprzedaż preparatów diagnostycznych w latach 1936-1937 (ze Sprawozdania PZH za rok 1937)

T A B L I C A XIII.

Sprzedaż organopreparatóze.

\begin{tabular}{|c|c|c|c|c|}
\hline \multirow[b]{2}{*}{ Nazwa preparatu } & \multicolumn{2}{|c|}{$\begin{array}{lllll}1 & 9 & 3 & 7 & \mathrm{r} .\end{array}$} & \multicolumn{2}{|c|}{$19936 \mathrm{r}}$. \\
\hline & $\begin{array}{l}\text { Ilość } \\
\text { w } \mathrm{cm}^{3}\end{array}$ & $\begin{array}{c}\text { Ilość } \\
\text { jednostek }\end{array}$ & $\begin{array}{c}\text { Ilośćc } \\
\mathrm{w} \mathrm{cm}^{3}\end{array}$ & $\begin{array}{c}\text { Ilość } \\
\text { jednostek }\end{array}$ \\
\hline 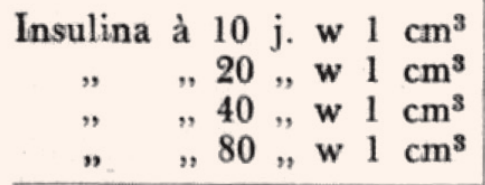 & $\begin{array}{r}675 \\
162.015 \\
277.845 \\
3.145\end{array}$ & $\begin{array}{r}6.750 \\
3.240 .300 \\
11.113 .800 \\
251.600\end{array}$ & $\begin{array}{r}2.505 \\
157.170 \\
234.890 \\
2.980\end{array}$ & $\begin{array}{r}25.050 \\
3.198 .400 \\
9.395 .600 \\
238.400\end{array}$ \\
\hline $\begin{array}{c}\text { Razem insulina w plynie } \\
, \quad " \quad \text { w proszku }\end{array}$ & $\begin{array}{l}443.680 \\
144 \mathrm{gram} .\end{array}$ & $\begin{array}{r}14.857 .450 \\
2.880 .000\end{array}$ & $\begin{array}{l}397.545 \\
108 \text { gram }\end{array}$ & $\begin{array}{r}12.857 .450 \\
2.160 .000\end{array}$ \\
\hline Razem jednostek & & 17.492 .450 & & 15.017 .450 \\
\hline$. \quad . \quad . \quad . \quad . \quad$. & 54.718 & 547.180 & 41.524 & 415.240 \\
\hline
\end{tabular}

Tabela V. Sprzedaż organo-preparatów w latach 1936 i 1937 (ze Sprawozdania PZH za rok 1937) 


\section{INSULINA PZH}

W styczniu 1924 r. wiceminister Zdrowia Publicznego Adamski wystosował list do prof. J.J.R.Macleoda w sprawie licencji na produkcję insuliny w Polsce i delegowania specjalistów do Toronto w celu poznania technologii produkcji. Osobą kierującą laboratorium był dr Kazimierz Funk w Oddziale Biochemii Państwowej Szkoły Higieny (do 1929 r.)

W 1924 r. wy produkowano w PZH (315 650 jednostek) insuliny, a w 1925 - 375400 jednostek.

Kierownik Działu Produkcji dr Józef Celarek (1886-1952) odbył podróże zagraniczne do ośrodków produkujących insulinę, aby zapoznać się z nowymi metodami produkcji.

Insulina była produkowana $\mathrm{w}$ płynie i w proszku (np. w 1934 r. - 23101 1, a w 1935 - 287345 litrów.) Insulina była badana w II klinice chorób wewnętrznych w Warszawie.

Państwowy Zakład Higieny był jedyną instytucją wytwarzającą insulinę w Polsce, a jej jakość nie odbiegała od wyrobów zagranicznych.

Roczna sprzedaż insuliny na potrzeby krajowe w 1937 r. wyniosła 14000000 jednostek. Za granicę sprzedano 3287000 jednostek.

Dochody ze sprzedaży insuliny ratowały budżet PZH w trudnych latach 30.

\section{PRODUKCJA SUROWIC I SZCZEPIONEK W CZASIE II WOJNY ŚWIATOWEJ}

Podczas wojny p.o. kierownikiem Działu Surowic i Szczepionek był bakteriolog dr Stanisław Saski (1.08.1939-1.08.1944) Produkcja była ograniczana, gdyż niemieckie kierownictwo PZH w obawie przed epidemiami duru plamistego skupiało głównie się na produkcji tej szczepionki.

W pracowni szczepionki przeciwko durowi plamistemu, utworzonej przez Niemców, produkowano szczepionkę metodą Weigla wyłącznie dla wojska niemieckiego. Kierował pracownią niemiecki lekarz Herman Wohlrab. Personel był polski; m.in. dr Jan Kostrzewski pod pseud. „Zarębski” i dr Juliusz Rychard - pseud." Klein”. Ponadto Polacy byli karmicielami wszy.

Tajną produkcję tej szczepionki dla ludności polskiej uruchomiono w Dziale Bakteriologii i Medycyny Doświadczalnej, którym kierował doc. Feliks Przesmycki. Produkcję prowadzili dr Edmund Wojciechowski i dr Tadeusz Przyborowski oraz laborant Edward Mikołajczyk. Oni też byli karmicielami wszy. Dr Jerzy Morzycki dostarczał szczepionkę do obozów koncentracyjnych, więzień, getta i na Pawiak. Ponadto zaszczepiono od 1942 r. cały personel szpitalny Warszawy.
Władze niemieckie rozszerzyły produkcję szczepionki przeciwko durowi plamistemu metodą jajową Coxa w Amelinie. Ta szczepionka była mało efektywna i wkrótce zaprzestano jej produkcji.

\section{ZAKŁAD PRODUKCJI PO II WOJNIE ŚWIATOWEJ}

Przy końcu kwietnia 1945 r. Dyrektor PZH Feliks Przesmycki polecił Wierze Głowackiej stawić się w filii PZH w Warszawie (Centrala mieściła się wtedy w Łodzi) do kierownika Oddziału Pasteurowskiego doktora Saskiego. Już w listopadzie 1945 r. Zakład Pasteurowski zaczął rozprowadzać szczepionkę przeciwko wściekliźnie własnej produkcji. Wiera Głowacka pracowała w Zakładzie Pasteurowskim do 15 sierpnia 1951 r. W tym roku Zakład Pasteurowski został odłączony od PZH i włączony do Warszawskiej Wytwórni Surowic i Szczepionek. W artykule „Z historii Państwowego Zakładu Higieny. Działalność Warszawskiego Zakładu Pasteurowskiego w latach 1945-1962" Wiera Głowacka przedstawiła działalność naukową i usługową Zakładu po II wojnie światowej z podziałem na 2 okresy: od 1945-1952 w ramach PZH i 19521962 - Zakład Pasteurowski po włączeniu do Warszawskiej Wytwórni Surowic i Szczepionek. W pierwszym okresie wyprodukowano 3719,68 litra szczepionki przeciwko wściekliźnie metodą Semple'a, udzielono 7985 porad i zaszczepiono 925 osób. W drugim okresie nie prowadzono w Zakładzie szczepień przeciw wściekliźnie. Sytuacja epizootyczna w Polsce była pomyślniejsza po przeprowadzeniu masowych szczepień zapobiegawczych psów. Jednak rejestracja szczepień i zużycie szczepionki nie były dokładnie rejestrowane przez terenowe służby sanitarne, co utrudniało śledzenie sytuacji epidemiologicznej wścieklizny.

Wiera Głowacka była autorką broszury"Co należy wiedzieć o wściekliźnie i o jej zapobieganiu (współautor: Abdon Stryszak). Cytat: „Książeczka niniejsza wydana z ramienia Państwowego Zakładu Higieny daje gwarancję prawdy naukowej i bezinteresowności"

Po wojnie produkcja surowic i szczepionek została wznowiona w Częstochowie (tam ewakuowano część urządzeń do produkcji szczepionki przeciwko durowi plamistemu ze Lwowa) w Krakowie, Lublinie (Wola Sławińska) i w Warszawie.

W 1946 r. zaczęto produkować penicylinę w Krakowie.

W 1951 r. zakłady produkujące szczepionki zostały odłączone od PZH. Utworzono Zjednoczenie Produkcji Surowic i Szczepionek. Powstały nowe zakłady produkcyjne. Od początku lat 50. badaniami naukowymi surowic i szczepionek m.in. wścieklizny zajmowały się w Państwowym Zakładzie Higieny: Zakład Badania Surowic i Szczepionek (kontrola państwowa 
surowic i szczepionek) i Zakład Epidemiologii, który prowadził i nadal prowadzi m.in. badania szczepionek przeciwko wściekliźnie i ocenia ich bezpieczeństwo wprowadzając nowoczesne metody biologii molekularnej do kontroli i oceny szczepów wirusa używanych do szczepień ludzi i zwierząt.

\section{PIŚMIENNICTWO}

1. Nitsch R. Surowice i szczepionki wraz z nauką o odporności.T.1.Warszawa: Gebethner i Wolff, 1921.

2. Celarek J. Zasady produkcji surowic leczniczych. Warszawa: Wyd. „DELTA”1931.

3. Feliks Przesmycki. Wspomnienia. Warszawa: PZH (Maszynopis w Bibliotece PZH)

4. Sprawozdania z działalności PZH za lata 1924-1925, 1926-1927, 1935, 1936, 1937, 1938.
5. Odczyny serodiagnostyczne stosowane przez Państwowy Zakład Higieny w Warszawie. Wyd. 2.Warszawa 1937.

6. Głowacka W. Z historii Państwowego Zakładu Higieny. Działalność Warszawskiego Zakładu Pasteurowskiego w latach 1945-1962.Przegl Epidemiol 1964;18(1):105110 .

7. Seroka D. Stulecie badań nad wścieklizną w Państwowym Zakładzie Higieny w Warszawie. Przegl Epidemiol 2017;71(1):119-132.

Otrzymano: 23.08.2018 r.

Zaakceptowano do publikacji: $10.12 .2018 \mathrm{r}$.

\section{Adres do korespondencji:}

Marta Gromulska

Redakcja Przeglądu Epidemiologicznego

Zakład Epidemiologii

Narodowego Instytutu Zdrowia Publicznego-PZH

e-mail: mgromulska@ pzh.gov.pl 